\title{
Use of biochar on two volcanic soils: effects on soil properties and barley yield
}

\author{
G. Curaqueo ${ }^{1 *}$, S. Meier ${ }^{1}$, N. Khan ${ }^{2,3}$, M. $\mathrm{Cea}^{4} \&$ R, Navia ${ }^{4}$ \\ ${ }^{I}$ Center of Amelioration and Sustainability of Volcanic Soils. BIOREN-UFRO. Universidad de La Frontera.. \\ Tетисо, Chile. \\ *Corresponding author: gustavo.curaqueo@ufrontera.cl \\ ${ }^{2}$ Centre for Environmental Risk Assessment and Remediation (CERAR), University of South Australia, Mawson \\ Lakes, SA, Australia. \\ ${ }^{3}$ School of Natural and Built Environments, University of South Australia, Mawson Lakes, SA, Australia. \\ ${ }^{4}$ Scientific and Technological Bioresources Nucleus \& Department of Chemical Engineering. Universidad de La \\ Frontera. Temuco, Chile
}

\begin{abstract}
The use of biochar in agricultural soils appears to be promising because it is known to improve soil properties and increase crop production. However, few studies have been conducted with biochar on volcanic soils. Two field experiments were conducted simultaneously to evaluate the effect of oat hull biochar (OBC) on various physical-chemical properties of two volcanic soils, an 'Inceptisol' and an 'Ultisol', and to evaluate the resulting effects on the yields of barley (Hordeum vulgare) grown on these soils. The OBC doses applied to field microplots were equivalent to $0,5,10$ and $20 \mathrm{Mg} \mathrm{ha}^{-1}$. The results showed that $\mathrm{pH}$, total exchangeable bases, and electrical conductivity increased at the highest dose of $\mathrm{OBC}$ in both soils. Glomalin-related soil protein (GRSP) was significantly high in the Ultisol at a rate of $20 \mathrm{Mg} \mathrm{OBC} \mathrm{ha}^{-1}$. Water-stable aggregates (WSA) and mean weight diameter (MWD) were enhanced at the highest doses of $\mathrm{OBC}$ in both soils. However, water-holding capacity (WHC) only increased in the Ultisol when amended with $\mathrm{OBC}$ at rates of 10 and $20 \mathrm{Mg} \mathrm{ha}^{-1}$. Barley yield (grain weight $\mathrm{m}^{-2}$ ) significantly increased at the highest OBC dose by $31.3 \%$ and $21.9 \%$ for crops grown on the Inceptisol and Ultisol, respectively. Significant relationships were observed between WHC and glomalin fractions $(r=0.81$, $p<0.01$ for easily extractable-GRSP and $r=0.62, p<0.01$ for Total-GRSP) as well as between organic C and WSA and both glomalin fractions. According to this study, biochar may be used effectively to improve the quality of these two volcanic soils and promote sustainable grain production.
\end{abstract}

Keywords: Aggregates, biochar, crop, grain, glomalin-related soil protein, volcanic soils. 


\section{Introduction}

In recent decades, food production has increased worldwide. However, this achievement is primarily the result of intensive agricultural management, which can contribute, in the long run, to soil degradation and climate change and can endanger the long-term viability of agroecosystems (Gliessman, 2002). One way to reduce this problem is to apply sustainable agriculture strategies that minimize adverse impacts of farming on the environment, e.g., a reduction of agrochemicals, while also increasing the interaction and synergism between various components of agroecosystems. For this purpose, new amendments are being developed by optimizing their physical, chemical and biological parameters to enhance soil quality. Biochar (BC) is an interesting alternative that can improve both soil quality and the sustainability of agroecosystems. $\mathrm{BC}$ is a material that is a product of the pyrolysis of biomass at temperatures below $700^{\circ} \mathrm{C}$ under a total or partial absence of oxygen $\left(\mathrm{O}_{2}\right)$ (Lehmann and Joseph, 2009). Its physicochemical properties, such as particle size distribution, surface area, pore structure, and nutrient contents, are closely related to the pyrolysis conditions as well as the feedstock material (Joseph et al., 2010). $\mathrm{BC}$ application to agricultural soils has become a promising option for sustainable agriculture due to its ability to improve physical, chemical, and biological soil properties (Atkinson et al., 2010; Ladygina and Rineau, 2013) and also improve plant yields (Baronti et al., 2010). BC also contributes to greenhouse gas mitigation through the production of compounds that are very resistant to decomposition (Vaccari et al., 2011)2011, with a co-benefit to agricultural systems. In this context, various studies have indicated that $\mathrm{BC}$ can resist chemical and microbial attacks (Atkinson et al., 2010); it remains in the soil longer than any other form of organic C (Kuzyakov et al., 2014)2014.

Another key factor involved in soil quality is the amelioration of soil aggregates, which influences water and nutrient retention, oxygen diffusion, the physical protection of organic matter, seed germination and root density in soils (Álvaro-Fuentes et al., 2008). Factors that influence the stability of soil aggregates have been reviewed widely. BC can improve the stability of soil aggregates (Liu et al., 2012). Moreover, arbuscular mycorrhizal fungi (AMF) can improve soil aggregation through the effects of the fungal mycelium and of glomalin (i.e., glomalin-related soil protein, GRSP), although various soil management regimes can differentially affect AMF activity and, obviously, the GRSP content of the soil (Curaqueo et al., 2011; Rillig and Mummey, 2006).

In the present study, we were particularly interested in the effects of biochar application on the GRSP content of the soil (Ladygina and Rineau, 2013). Recent studies have indicated that $\mathrm{BC}$ application can increase the root colonization of AM fungi in various types of soils (Warnock et al., 2010). However, the relationship among soil biochar amendment, GRSP content and soil aggregate stability has not been fully studied. 
The aim of this study was to evaluate the effect of oat hull biochar (OBC) on the physicalchemical properties and glomalin content of an Inceptisol and an Ultisol of southern Chile and also on the growth and grain yields of barley grown in these soils.

\section{Materials and Methods}

\subsection{Field trials}

Field trials were conducted at two sites in the La Araucanía Region of southern Chile. The first site was located in the Quino-Chufquén area $\left(38^{\circ} 22^{\prime} \mathrm{S}, 72^{\circ} 37^{\prime} \mathrm{W}\right)$. The terrain at this site was flat, with $\mathrm{a}<2 \%$ slope, and the soil was an Inceptisol (Humic Fluventic Dystrudepts): slightly deep, with a silt loam surface texture, low permeability and good drainage. The second site was located in the Pumalal area $\left(38^{\circ} 38^{\prime} \mathrm{S}\right.$, $\left.72^{\circ} 29^{\prime} \mathrm{W}\right), 16 \mathrm{~km}$ northeast of Temuco. The soil at the site was an Ultisol (Typic Paleudults): moderately deep, with a loamy-silt-clay superficial texture, good drainage and a slight slope $(<5 \%$ incline). Rolling hills were present in the vicinity of the site.

OBC was produced by combusting oat hull feedstock in a pyrolysis unit at $300^{\circ} \mathrm{C}$ for $2 \mathrm{~h}$ at the Center of Waste Management and Bioenergy, Universidad de La Frontera. In this study, OBC was applied at a rate equivalent to $0,5,10$ and $20 \mathrm{Mg} \mathrm{ha}^{-1}$ by localized inter-row application on the surface soil of microplots $(1.5 \mathrm{~m} \times 3.5 \mathrm{~m})$ containing barley seedlings (Hordeum vulgare
L. cv Sebastian) (1-2 leaves). The OBC doses here applied were realistic in the context of the agricultural practices currently used in southern Chile.

Before barley sowing, both soils were plowed twice with a disk harrow, followed by one pass with a vibro-cultivator. At both sites, the barley seeds were sown in winter (August) with a conventional drill at a rate of $140 \mathrm{~kg}$ $\mathrm{ha}^{-1}$ with a distance of $17 \mathrm{~cm}$ between rows. Both soils were fertilized with urea, triple superphosphate and muriate of potash. A total of $70 \mathrm{~kg} \mathrm{~N} \mathrm{ha} a^{-1}, 120 \mathrm{~kg} \mathrm{P} \mathrm{ha-1}$, and $87 \mathrm{~kg} \mathrm{~K}$ $\mathrm{ha}^{-1}$ was applied at sowing and $80 \mathrm{~kg} \mathrm{~N} \mathrm{ha}^{-1}$ at the internode elongation growth stage in the Inceptisol microplots, whereas the Ultisol microplots received $60 \mathrm{~kg} \mathrm{~N} \mathrm{ha}^{-1}, 69 \mathrm{~kg} \mathrm{P}^{-}$ ${ }^{1}$, and $76 \mathrm{~kg} \mathrm{~K} \mathrm{ha}^{-1}$ at sowing and $70 \mathrm{~kg} \mathrm{~N}$ $\mathrm{ha}^{-1}$ at the internode elongation growth stage. Weeds were controlled with $750 \mathrm{~g}$ 2-methyl4-chlorophenoxyacetic acid (MCPA) $\mathrm{ha}^{-1}$ and $8 \mathrm{~g}$ metsulfuron methyl ha-1.

\subsection{Soil and biochar characterization}

The chemical properties $(\mathrm{N}, \mathrm{P}, \mathrm{K}, \mathrm{pH}$, interchangeable bases, Al saturation) of the field soils and the biochar were determined according to Sadzawka et al. (2005; 2006). Total $\mathrm{C}$ and $\mathrm{N}$ were determined by dry combustion in a VARIO/EL C, H, N, S analyzer (Elementar Analysensysteme $\mathrm{GmbH}$, Germany). Selected properties of the soils and the $\mathrm{BC}$ are shown in Table 1. 
Table 1. Selected properties 0-20 cm depth of two soils Inceptisol and Ultisol and oat hull biochar.

\begin{tabular}{|c|c|c|c|}
\hline Parameter $^{*}$ & Inceptisol & Ultisol & Biochar \\
\hline $\mathrm{N}\left(\mathrm{mg} \mathrm{kg}^{-1}\right)$ & 19 & 22 & 4 \\
\hline $\mathrm{P}\left(\mathrm{mg} \mathrm{kg}^{-1}\right)$ & 7 & 27 & 21 \\
\hline $\mathrm{K}\left(\mathrm{mg} \mathrm{kg}^{-1}\right)$ & 317 & 188 & 1122 \\
\hline $\mathrm{pH}$ (water) & 5.85 & 5.68 & 7.4 \\
\hline Organic matter $(\%)$ & 7 & 8 & -- \\
\hline Interchangeable $\mathrm{K}\left(\mathrm{cmol}+\mathrm{kg}^{-1}\right)$ & 0.81 & 0.48 & 2.87 \\
\hline Interchangeable $\mathrm{Na}\left(\mathrm{cmol}+\mathrm{kg}^{-1}\right)$ & 0.05 & 0.04 & 0.14 \\
\hline Interchangeable $\mathrm{Ca}\left(\mathrm{cmol}+\mathrm{kg}^{-1}\right)$ & 9.20 & 6.23 & 1.23 \\
\hline Interchangeable $\mathrm{Mg}\left(\mathrm{cmol}+\mathrm{kg}^{-1}\right)$ & 2.79 & 1.17 & 0.52 \\
\hline Interchangeable $\mathrm{Al}\left(\mathrm{cmol}+\mathrm{kg}^{-1}\right)$ & 0.01 & 0.29 & 0.01 \\
\hline Al saturation (\%) & 0.08 & 3.53 & 0.21 \\
\hline $\mathrm{ECEC}^{* *}\left(\mathrm{cmol}+\mathrm{kg}^{-1}\right)$ & 12.86 & 8.21 & 4.77 \\
\hline Total exchangeable bases $\left(\mathrm{cmol}+\mathrm{kg}^{-1}\right)$ & 12.85 & 7.92 & 4.76 \\
\hline Density $\left(\mathrm{g} \mathrm{cm}^{-3}\right)$ & 1.16 & 1.03 & 0.18 \\
\hline Total C (\%) & -- & -- & 70.13 \\
\hline Total N (\%) & -- & -- & 1.03 \\
\hline C:N Ratio (\%) & -- & -- & 68.1 \\
\hline
\end{tabular}

*According Sadzawka et al. (2006). ECEC: Effective cation exchange capacity

\subsection{Plant and soil analyses}

To evaluate the crop response to the biochar, relative leaf chlorophyll concentration (SPAD value), plant height and grain yields were measured. The SPAD value was measured randomly on the top three completely expanded leaves per hill on day 60 after sowing (60 DAS) according to Asai et al. (2009) using a SPAD520 Chlorophyll Meter (Konica Minolta Inc.); the mean of six hills was calculated. At the same time, plant height was also recorded from the 
soil surface to the tip of the spike, excluding awns. For all the treatments, grain yields were measured at the end of the crop cycle (approximately $180 \mathrm{DAS}$ ) by harvesting a whole plot except for the plants on the plot border.

Root zone soil samples from depths of $0-20 \mathrm{~cm}$ were collected 15 days after the plant harvest. Soil bulk density was performed by the cylinder $(\mathrm{d}=5 \mathrm{~cm})$ method using a $5-\mathrm{cm}$ diameter cylinder. Total soil porosity was calculated using the data obtained from the bulk density relative to a real density of $2.65 \mathrm{~g} \mathrm{~cm}^{-3}$.

The water-holding capacity (WHC) was measured according to the methodology described by Curaqueo et al. (2011). Briefly, $20 \mathrm{~g}$ of soil sample was placed in a funnel with an absorbent membrane. The soil samples were saturated with distilled water until the excess water was removed by gravity. Once equilibrium was reached, the WHC was calculated based on the weight of the water held in the sample vs. the weight of the dried sample.

The water-stable soil aggregates (WSA), particle size distribution and mean weight diameter (MWD) were measured according to Kemper and Rosenau (1986). Briefly, air-dried and sieved $(1 \mathrm{~mm})$ soil was placed in a $0.250 \mathrm{~mm}$ sieve and immersed in an aluminum pan containing distilled water for $3 \mathrm{~min}$. The procedure used a stroke length of $1.3 \mathrm{~cm}$ and a frequency of 35 cycles $\mathrm{min}^{-1}$. The soil deposited in the aluminum pan was then totally dried at $105^{\circ} \mathrm{C}$. The soil retained in the sieve was again immersed in an aluminum pan containing $\mathrm{NaOH}$ solution $\left(2 \mathrm{~g} \mathrm{~L}^{-1}\right)$ for $15 \mathrm{~min}$ at a frequency of 35 cycles $\mathrm{min}^{-1}$. The soil placed in the aluminum pan in this step was then totally dried at $105^{\circ} \mathrm{C}$. The two aggregate fractions (from water and $\mathrm{NaOH}$ ) were weighed to obtain the WSA percentage. The particle size distribution was determined in a vibratory sieve shaker (Retsch AS200, Retsch Technology, Germany) that consisted of six sieves (6.30, 4.75, $2.00,1.18,0.250$, and $0.125 \mathrm{~mm}$ mesh) using an amplitude of $1.5 \mathrm{~mm}$ for $2 \mathrm{~min}$. After sieving, the mean weight diameter (MWD, mm) was calculated using the following equation:

$$
\mathrm{MWD}=\sum_{i=1}^{n} \bar{X}_{i} W_{i},
$$

where ${ }_{i}$ is the arithmetic mean diameter of the aggregates in the $i+1$ and $i$ sieving openings (mm), $W_{i}$ is the proportion of weight (weight of aggregates in the $i$ size fraction $(\mathrm{g}) /$ total soil weight $(\mathrm{g}))$ of the aggregates, and $n$ is the number of size fractions.

Soil $\mathrm{pH}$ and electrical conductivity (EC) were determined in a 2:5 (w:v) aqueous solution. Available $\mathrm{P}$ was extracted with $0.5 \mathrm{M} \mathrm{NaHCO}_{3}$ solution at $\mathrm{pH} 8.5$ and quantified according to Olsen and Sommers (1982). Soil C content was determined according to Walkley and Black (1934). Total exchangeable bases were obtained by extracting the available $\mathrm{Ca}, \mathrm{Mg}$, $\mathrm{Na}$ and $\mathrm{K}$ using $1 \mathrm{M} \mathrm{CH}_{3} \mathrm{COONH}_{4}$ solution at pH 7.0 (Sadzawka et al., 2006).

The GRSP fractions were obtained according to Wright and Upadhyaya (1996). The easily extractable GRSP fraction (EE-GRSP) was obtained from $1 \mathrm{~g}$ of soil placed in $8 \mathrm{~mL}$ of citrate buffer (20 mM, pH 7.0) and autoclaved at $121^{\circ} \mathrm{C}$ for $30 \mathrm{~min}$. Total GRSP (T-GRSP) was extracted from $1 \mathrm{~g}$ of soil placed in $8 \mathrm{~mL}$ of $50 \mathrm{mM}$ citrate buffer at $\mathrm{pH} 8.0$ and autoclaved for $1 \mathrm{~h}$ at $121^{\circ} \mathrm{C}$, repeating this procedure several times until the 
typical reddish-brown color of GRSP disappeared from the supernatant. Both fractions were then centrifuged at $8000 \mathrm{x} \mathrm{g}$ for $15 \mathrm{~min}$ followed by filtration through Whatman No. 1 paper. The glomalin contents (i.e., EE-GRSP and T-GRSP) were determined with a Bradford protein assay (Bio Rad Protein Assay; Bio Rad Labs) with bovine serum albumin as the standard.

\subsection{Experimental design and statistical analysis}

The experiments followed a completely randomized design with four doses of $\mathrm{BC}$ $\left(0,5,10,20 \mathrm{Mg} \mathrm{ha}^{-1}\right)$ and four replications. The data obtained were statistically analyzed using a one-way ANOVA, and the means were compared using a Tukey test $(p \leq$ $0.05)$. A correlation analysis was performed using a Pearson coefficient to evaluate the linear relationships between pairs of studied variables. All the statistical analyses were performed using SPSS version 14 (SPSS Inc., Chicago, IL, USA).

\section{Results}

\subsection{Plant analyses}

Table 2 presents the effects of BC on barley growth and grain yield. In the Inceptisol, the chlorophyll relative concentration or leaf SPAD was negatively affected by the highest OBC treatment; while the plant height was not affected. In contrast, in the Ultisol, OBC at 20 $\mathrm{Mg}$ ha $^{-1}$ significantly increased plant height by $24 \%$; however, the leaf SPAD was not affected. The addition of the highest OBC dose $(20 \mathrm{Mg}$ $\mathrm{ha}^{-1}$ ) significantly increased grain yield in the microplots by $31.3 \%$ and $21.8 \%$ in the Inceptisol and Ultisol, respectively, relative to the control.

\subsection{Soil analyses}

The OBC application produced contrasting effects on bulk density and porosity in both soils (Table 3). In general, bulk density decreased with the higher OBC doses, but significant differences were observed only in the Inceptisol. In the Ultisol, porosity increased at the highest OBC dose, but no significant differences were observed.

In both soils, a trend of increasing WHC was observed with higher doses of OBC. In the Ultisol, WHC differed significantly among the treatments, ranging from $50.8 \%$ for the control to $65.6 \%$ for $20 \mathrm{Mg}$ OBC ha-1. In contrast, the Inceptisol showed lower and non-significant differences in WHC, ranging from $38.5 \%$ in the control to $42.0 \%$ for the highest dose of OBC $\left(20 \mathrm{Mg} \mathrm{ha}^{-1}\right)$. An increase in WSA relative to the control was observed at the higher doses of OBC (10 and $20 \mathrm{Mg}$ ha $^{-1}$ ). All treatments had WSA $>35 \%$ in both soils, ranging from $36.24 \%$ to $42.0 \%$ in the Inceptisol to $41.09 \%$ to $53.55 \%$ in the Ultisol. OBC significantly increased the MWD of soil aggregates by $54 \%$ and $50 \%$ in the Inceptisol and the Ultisol, respectively. The diameters of the aggregates were typically in the $\geq 1.18 \mathrm{~mm}$ class in all treatments for both soils (Figure $1)$. In the Inceptisol, the aggregate fraction $\geq 1.18 \mathrm{~mm}$ increased from $60 \%$ of the total soil particle distribution to $\sim 80 \%$ due to the OBC. In the Ultisol, however, this trend was inconsistent, although the same aggregate fraction exceeded $60 \%$ at $10 \mathrm{Mg} \mathrm{ha}^{-1}$ of OBC. 
Table 2. Effect of oat hull biochar on Leaf SPAD, plant height and grain yield of barley in two volcanic soils of southern Chile.

\begin{tabular}{|c|c|c|c|c|c|c|}
\hline Treatments & Leaf SPAD & $\begin{array}{l}\text { Height } \\
(\mathrm{cm})\end{array}$ & $\begin{array}{l}\text { Grain Yield } \\
\left(\mathrm{kg} \mathrm{m}^{-2}\right)\end{array}$ & Leaf SPAD & $\begin{array}{l}\text { Height } \\
(\mathrm{cm})\end{array}$ & $\begin{array}{l}\text { Grain Yield } \\
\left(\mathrm{kg} \mathrm{m}^{-2}\right)\end{array}$ \\
\hline & \multicolumn{3}{|c|}{ Inceptisol } & \multicolumn{3}{|c|}{ Ultisol } \\
\hline $0 \mathrm{Mg} \mathrm{BC} \mathrm{ha-1}$ & $47.15 \pm 0.9 \mathrm{ab}$ & $33.1 \pm 0.6$ & $2.17 \pm 0.15 b$ & $46.35 \pm 1.0$ & $30.7 \pm 1.0 \mathrm{c}$ & $2.35 \pm 0.16 \mathrm{~b}$ \\
\hline $5 \mathrm{Mg} \mathrm{BC} \mathrm{ha}^{-1}$ & $49.38 \pm 1.2 \mathrm{a}$ & $36.2 \pm 5.9$ & $2.38 \pm 0.06 b$ & $47.85 \pm 0.6$ & $33.5 \pm 1.7 \mathrm{bc}$ & $2.59 \pm 0.06 \mathrm{ab}$ \\
\hline $10 \mathrm{Mg} \mathrm{BC} \mathrm{ha}^{-1}$ & $45.82 \pm 1.1 \mathrm{ab}$ & $33.1 \pm 1.2$ & $2.53 \pm 0.11 \mathrm{ab}$ & $43.27 \pm 4.3$ & $34.8 \pm 1.1 \mathrm{~b}$ & $2.75 \pm 0.12 \mathrm{ab}$ \\
\hline $20 \mathrm{Mg} \mathrm{BC} \mathrm{ha}^{-1}$ & $43.76 \pm 1.4 b$ & $33.1 \pm 1.5$ & $2.85 \pm 0.05 \mathrm{a}$ & $46.97 \pm 1.9$ & $38.2 \pm 0.1 \mathrm{a}$ & $2.87 \pm 0.06 \mathrm{a}$ \\
\hline \multicolumn{7}{|l|}{ ANOVA } \\
\hline$F$-value & 8.346 & 0.490 & 8.030 & 1.335 & 14.612 & 3.997 \\
\hline$P$-values & 0.003 & NS & 0.003 & NS & $<0.001$ & 0.035 \\
\hline
\end{tabular}

Mean \pm standard error for each measure is given. In a column, different letters indicate significant differences among treatment according to the Tukey test $(p \leq 0.05)$.

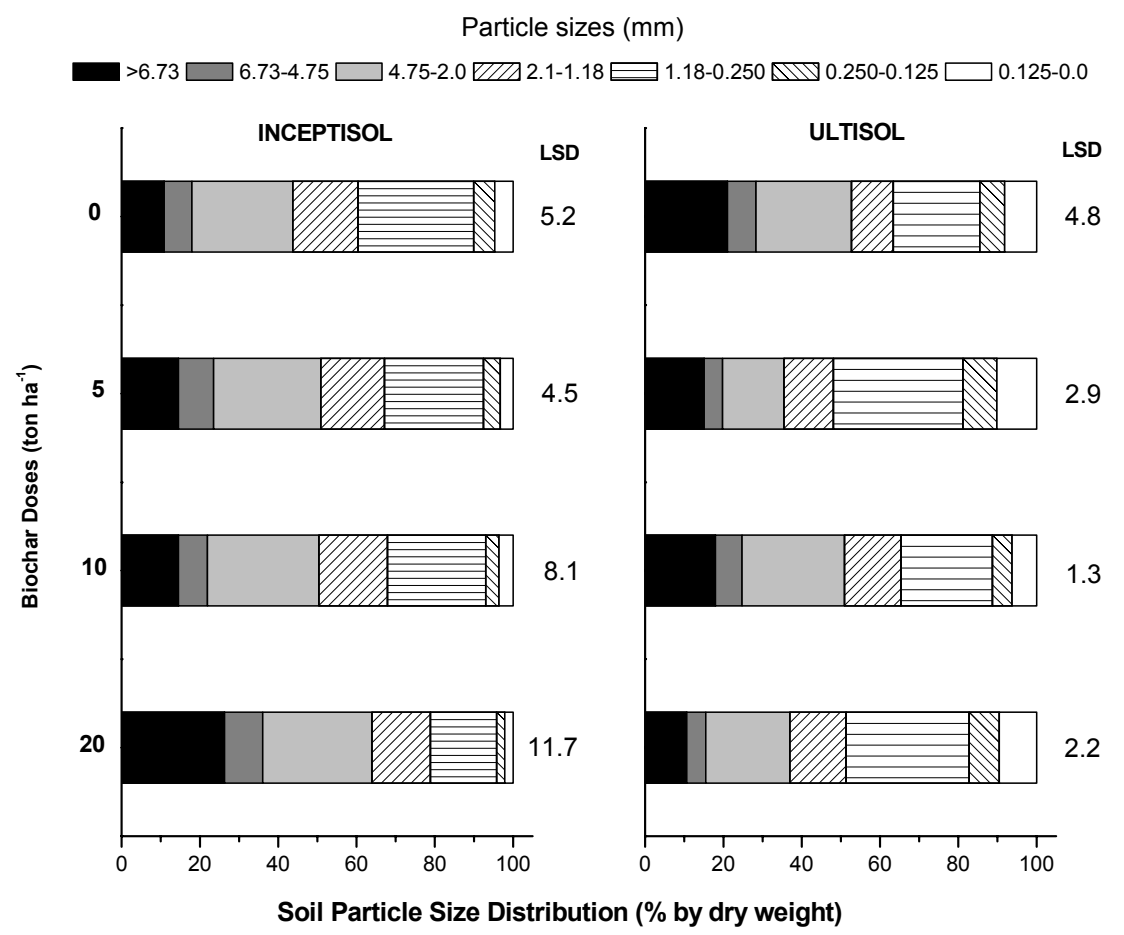

Figure 1. Soil particle size distribution in two volcanic soils of southern Chile after application of oat hull biochar at four doses. LSD values indicate the differences among particle size fractions. 
In both soils, $\mathrm{OBC}$ addition increased $\mathrm{pH}$, total exchangeable bases and EC. Its effect on other soil parameters such as available $\mathrm{P}$, organic $\mathrm{C}$, bulk density, porosity, and WHC were divergent, depending mainly on the soil type (Table 3 ). $\mathrm{pH}$ values ranged from 5.2 to 5.5 and 5.9 to 6.5 for the control and $20 \mathrm{Mg} \mathrm{OBC} \mathrm{ha}^{-1}$, respectively, in both the Inceptisol and the Ultisol, respectively. In the Inceptisol, the available P was $<7.4 \mathrm{mg}$ $\mathrm{kg}^{-1}$ in all treatments. However, a significant difference was observed between the soils treated with the amendment and the control soils. In contrast, in the Ultisol, the available $\mathrm{P}$ was $>26.9 \mathrm{mg} \mathrm{kg}^{-1}$, and no significant differences were observed between the soils treated with the amendment and the control soils. The organic $\mathrm{C}$ content was not affected by the treatments in either soil. The total exchangeable bases and EC were increased in both soils, particularly at application rates of 10 and $20 \mathrm{Mg} \mathrm{BC} \mathrm{ha-1.}$

In both soils, an increasing trend in the content of EE-GRSP and T-GRSP was observed at higher $\mathrm{BC}$ doses. However, there were no significant differences in most of the cases. For the Inceptisol, the EE-GRSP content ranged from 2.47 to $2.93 \mathrm{mg} \mathrm{g}^{-1}$, and the T-GRSP content ranged from 6.49 to $7.29 \mathrm{mg} \mathrm{g}^{-1}$. For the Ultisol, the EE-GRSP content ranged from 3.06 to $3.30 \mathrm{mg} \mathrm{g}^{-1}$, and the T-GRSP content ranged from 7.35 to $8.38 \mathrm{mg} \mathrm{g}^{-1}$ (Table 3 ).

Table 3. Effect of $\mathrm{OBC}$ application at different rates on some parameters $(0-20 \mathrm{~cm}$ depth) of two volcanic soils.

\begin{tabular}{|c|c|c|c|c|c|c|c|c|c|c|c|c|}
\hline Treatments & $\mathrm{pH}$ & $\begin{array}{c}\text { Available P } \\
\text { (mg kg') }\end{array}$ & Organic C & $\begin{array}{c}\text { Total exchangeable } \\
\text { bases } \\
\left.\text { (cmol+ } \mathrm{kg}^{\prime}\right)\end{array}$ & $\left(\begin{array}{c}\mathrm{C} \\
(\mathrm{S} \mathrm{cm})\end{array}\right.$ & $\begin{array}{c}\text { EE-GRSP } \\
\text { (mge's }\end{array}$ & $\begin{array}{l}\text { T-GRSP } \\
\left(m g g^{\prime}\right)\end{array}$ & $\begin{array}{c}\text { Bulk density } \\
\left(\mathrm{g} \mathrm{cm}^{-3}\right)\end{array}$ & $\begin{array}{c}\text { Porosity } \\
(\%)\end{array}$ & $\begin{array}{r}\text { MWD } \\
(\mathrm{mm})\end{array}$ & $\begin{array}{c}\text { WHC } \\
(\%)\end{array}$ & $\begin{array}{l}\text { WSA } \\
(\%)\end{array}$ \\
\hline \multicolumn{13}{|c|}{ Inceptisol } \\
\hline $6 \mathrm{Mg} \mathrm{BC} \mathrm{ha}^{-1}$ & $5.2+0.04 \mathrm{bb}$ & $7.1 \pm 0.06 \mathrm{~F}$ & $40 \%+a 02$ & $12.99+0.006$ & $506 \pm 62 \mathrm{~b}$ & $2.47 \pm 0.12$ & $6.49 \pm 0.73$ & $1.29 \pm 0.04 b$ & $51.3 \pm 1.76$ & $2.70=0.32 \mathrm{~b}$ & $38.5 \pm 0.5$ & $36.24 \div 3.596$ \\
\hline $5 \mathrm{Mg} \mathrm{BCha-1}^{-1}$ & $3.3+0.04 \mathrm{~b}$ & $7,1 \pm 0.05$ ste & $408+001$ & $13.06 \pm 0.05 b$ & $6 \pi \pm 22$ & $2.76 \pm 0.20$ & $6.63 \pm 0.38$ & $1.15 \pm 0,02 a$ & $56,4 \pm 0.62$ & $3,03 \div 0.38 \mathrm{sab}$ & $39,1 \pm 0,7$ & $39.58 \pm 2.856$ \\
\hline $10 \mathrm{Mg} \mathrm{BCh}^{-2}$ & $3.3+0.01 \mathrm{~b}$ & $7,3+0.03 \mathrm{ub}$ & $4.10 \pm 0.03$ & $13.18+0.11 \mathrm{~b}$ & $725 \pm 102$ & $2.76 \pm 0.16$ & $6.98+101$ & $1.21+0,05 \mathrm{sb}$ & $54,3+2.0 \mathrm{ab}$ & $3.17 \pm 0.29 \mathrm{ab}$ & $39.6 \pm 1.6$ & $44.80 \pm 2.76 \mathrm{~s}$ \\
\hline $20 \mathrm{Mg} \mathrm{BC} \mathrm{ha}^{-4}$ & $59 \pm 0.07 a$ & $7.4+0.05 \mathrm{a}$ & $4.12+0.02$ & $13.47 \pm 0.192$ & $758 \pm 454$ & $2.93+0.18$ & $730 \div 0.49$ & 1.19+0.02ab & 35. $1+0.9 \mathrm{ab}$ & $4.16 \pm 0.65 a$ & $42.0+3.5$ & $49.08+2.904$ \\
\hline \multicolumn{13}{|l|}{ ANOVA } \\
\hline F.Value & 16.313 & 15374 & 1.718 & 14.962 & 15,682 & 2.550 & 0.543 & 4.778 & 4.740 & 4.143 & 1.272 & 6.939 \\
\hline$P$. Values & $\$ 0001$ & -0.001 & $\mathrm{NS}$ & 0.001 & 0.001 & $\mathrm{NS}$ & NS & 0.0100 & 0.021 & 0.031 & NS & 0.006 \\
\hline \multicolumn{13}{|c|}{ Utinod } \\
\hline $0 \mathrm{Mg} \mathrm{BCha}^{-1}$ & $5900 \% 7$ & 26.940 .49 & $4.81 \div 004$ & $7.8240 .03 \mathrm{~s}$ & $272+3 \mathrm{~b}$ & $3.06+0.04$ & $7.35 \div 0.14 \mathrm{~b}$ & $1.02+0.05$ & $61.6 \div 1.7$ & $287\llcorner 0.01 \mathrm{lc}$ & $50.8+0.5 \mathrm{c}$ & $41.09+3.52 \mathrm{~s}$ \\
\hline $5 \mathrm{Mg} \mathrm{BC} \mathrm{ha}^{-1}$ & $6.1 \pm 0.06 \mathrm{~b}$ & $270 \pm 0.08$ & $4.83 \pm 004$ & $7.97 \pm 0.036$ & $300+3 \pi$ & $3.10 \div 0.12$ & $7.45 \pm 0.17 \mathrm{~b}$ & $1.01 \pm 0.05$ & $62.1=19$ & $3.15 \pm 0.19 \mathrm{t}$ & $52,3 \pm 0.7 \mathrm{c}$ & $45.05 \pm 4.60 \mathrm{sh}$ \\
\hline $10 \mathrm{Mg} \mathrm{BCha}^{-1}$ & $62+0.01 \mathrm{~b}$ & $27.1=0.23$ & $4.85 \div 0.03$ & $8.03 \pm 0.030 b$ & $314 \pm 4 \mathrm{~b}$ & $3.23+0.09$ & $7.51=0.096$ & $1.01 \pm 0.02$ & $620=09$ & $399=000 \mathrm{db}$ & $56,0 \pm 0.8 \mathrm{~b}$ & $49.63 \pm 3.06 \mathrm{~s}$ \\
\hline $20 \mathrm{Mg} \mathrm{BC} \mathrm{ha}^{-4}$ & $65 \pm 002 a$ & $27.4 \pm 0.17$ & $4.87 \pm 0.05$ & $8.09=0.023$ & $556+92$ & $3.30+0.11$ & $8.30=0.18 \mathrm{a}$ & $0.99=0.02$ & $62.8 \pm 0.6$ & $4.33 \pm 0.12 \mathrm{a}$ & $65,6 \pm 0.6 \mathrm{a}$ & $5355 \pm 3.17 a$ \\
\hline \multicolumn{13}{|l|}{ ANOVA } \\
\hline$F$-Value & 53.439 & 1.109 & 0.969 & 32.913 & 95.629 & 2.937 & 22.730 & 0.237 & 0.228 & 74.893 & 278.593 & 4.439 \\
\hline PV Vuluex & $\triangle 0001$ & NS & Ns & -0.001 & 40.001 & $\mathrm{Ns}$ & 0.001 & Ns & Ns & $\$ 0001$ & 0.001 & 0.0226 \\
\hline
\end{tabular}

Mean \pm standard error for each measure is given. In a column, different letters in the same soil indicate significant differences among treatments assayed systems according to the Tukey test $(p \leq 0.005)$. EC: Electrical conductivity. EE-GRSP: Easily extractable glomalin related soil protein. T-GRSP: Total glomalin related soil protein. MWD: Mean weight diameter. WSA: Water stable aggregates. WHC: Water holding capacity. 


\subsection{Relationship among observed parameters}

Several positive relationships were found between various observed parameters (Table 4). Strong correlations were found between organic $\mathrm{C}$ and porosity $(r=0.88, p<0.01)$ and between organic $\mathrm{C}$ and WHC $(r=0.89, p<0.01)$. Organic C showed positive correlations with both GRSP and EE-GRSP ( $r=0.53, p<0.01 ; r=0.72, p<0.01$, respectively). WSA and MWD also showed positive correlations with both GRSP fractions. EE-GRSP and GRSP showed positive correlations with WHC $(r=0.62$, $p<0.01 ; r=0.81, p<0.01$, respectively).

Table 4. Correlation matrix of some selected parameters studied.

\begin{tabular}{|c|c|c|c|c|c|c|c|c|c|}
\hline Parameters & $\mathrm{pH}$ & $\begin{array}{l}\text { Bulk } \\
\text { density }\end{array}$ & Porosity & WHC & Yield & WSA & MWD & T-GRSP & $\begin{array}{l}\text { EE- } \\
\text { GRSP }\end{array}$ \\
\hline Organic C & $0.93^{*} *$ & $-0.88 * *$ & $0.88^{*} *$ & $0.89^{*} * k^{2}$ & $0.40^{*}$ & $0.41^{*}$ & $0.25 \mathrm{~ns}$ & $0.53 * *$ & $0.72 * *$ \\
\hline Available P & $0.92^{* *}$ & $-0.88 * *$ & $0.88 * *$ & $0.88^{*} *$ & $0.39 *$ & $0.38^{*}$ & $0.24 \mathrm{~ns}$ & $0.51 * *$ & $0.72 * *$ \\
\hline Total exchangeable bases & $-0.90 * *$ & $0.86 * *$ & $-0.87 * *$ & $-0.86 * *$ & $-0.34 n s$ & $-0.32 \mathrm{~ns}$ & $-0.18 n s$ & $-0.49 * *$ & $-0.70 * *$ \\
\hline $\mathrm{EC}$ & $-0.56 * *$ & $0.62 * *$ & $-0.62^{* *}$ & $-0.48 *$ & $0.05 \mathrm{~ns}$ & $0.03 \mathrm{~ns}$ & $0.18 \mathrm{~ns}$ & $-0.18 n s$ & $-0.3 \operatorname{lns}$ \\
\hline EE-GRSP & $0.80 * *$ & $-0.70 * *$ & $0.70 * *$ & $0.81 * *$ & $0.63^{* *}$ & $0.55^{* *}$ & $0.51 * *$ & $0.62 * *$ & \\
\hline T-GRSP & $0.61^{*} *$ & $-0.58 * *$ & $0.58 * *$ & $0.62 * *$ & $0.45^{*}$ & $0.50 * *$ & $0.59 * *$ & & \\
\hline MWD & $0.47^{* *} *$ & $-0.29 \mathrm{~ns}$ & $0.29 \mathrm{~ns}$ & $0.51 * *$ & $0.58 * *$ & $0.68^{*} *$ & & & \\
\hline WSA & $0.59^{*}$ * & $-0.43 n s$ & $0.43^{*}$ & $0.54 * *$ & $0.62^{* *}$ & & & & \\
\hline Grain yield & $0.58 * *$ & $-0.52^{*}$ & $0.52^{* * *}$ & $0.56^{* *}$ & & & & & \\
\hline WHC & $0.96^{* *}$ & $-0.78 * *$ & $0.78^{* *}$ & & & & & & \\
\hline Porosity & $0.84^{*} *$ & $-0.99 * *$ & & & & & & & \\
\hline Density & $-0.84 * *$ & & & & & & & & \\
\hline
\end{tabular}

Pearson correlation coefficients ( $r)$ were calculated from four replicates of each sampling situation $(n=32)$. EC: Electrical conductivity. EE-GRSP: Easily extractable glomalin related soil protein. T-GRSP: Total glomalin related soil protein. MWD: Mean weight diameter. WSA: Water stable aggregates. WHC: Water holding capacity. Significance conventions: ${ }^{*} p \leq 0.05 . * * p \leq 0.01$. ns $=$ not significant. 


\section{Discussion}

The effect of OBC on the crop parameters varied under the given test conditions (Table 2). The higher BC doses resulted in higher barley grain yields relative to the control. Increases in plant height, biomass growth and grain yield under biochar amendments have been widely reported (Alburquerque et al., 2013; Baronti et al., 2010; Varela Milla et al., 2013). However, contrasting findings are also common (Mukherjee and Lal, 2014). It is well known that biochar improves soil fertility (Major et al., 2010; Schulz et al., 2013), acting as a good source of $\mathrm{K}$ and, to a lesser extent, of $\mathrm{P}$ for crop nutrition. The increase in grain yields can be related to these effects (Alburquerque et al., 2013). The $\mathrm{pH}$, total exchangeable bases and EC increased with the treatments applied in this study. This increase might have increased the availability of nutrients (Atkinson et al., 2010; Laird et al., 2010; Major et al., 2010) and stimulated root activity (Khan and Shea, 2013).

Both the EE-GRSP and T-GRSP fractions in the soils increased at higher doses of OBC. However, the glomalin concentrations were similar to those found in two Ultisols from southern Chile under plowing management (Borie et al., 2006; Morales et al., 2005). Higher concentrations of both glomalin types are also generally observed in soils after the addition of various other organic sources, such as manure, crop stubble, or compost (Curaqueo et al., 2011; Curaqueo et al., 2014; Valarini et al., 2009), but the concentration of glomalin is also affected by soil management (Curaqueo et al., 2011)

Bulk density in soils decreased with higher BC doses, in contrast to the findings of previous studies (Laird et al., 2010). The effect of biochar on soil bulk density appears to develop in the long term, or at least over a period of 2 years after its application (Mukherjee and Lal, 2013). However, it depends on the soil type, organic matter content, tillage management, physical properties and doses of biochar. Porosity is a soil property closely related to soil bulk density, MWD and WHC (Curaqueo et al., 2011); in our study, higher density values were related to a reduced soil porosity. This study showed differential effects of the OBC doses. These effects were related to the type of soil, although, in general, the values of all these parameters increased with increasing amounts of biochar (Glaser et al., 2002).

Several studies have demonstrated that biochar can positively influence the formation of soil aggregates and their stability (Glaser et al., 2002; Liu et al., 2012; Ouyang et al., 2013). In this study, OBC doses significantly increased WSA in both soils. Both the particle size distribution and MWD in the Inceptisol increased with the OBC doses; however, in the Ultisol, MWD increased consistently, whereas the particle size distribution did not. The influence of $\mathrm{OBC}$ on aggregate stability and the particle size distribution could be related to the soil organic matter content as well as to other aggregation agents, such as glomalin fractions and/ or carbohydrates (Curaqueo et al., 2011; Spohn and Giani, 2010). Plowing breaks up larger and unstable aggregates and results in a smaller MWD. The increase in the smaller aggregates most likely contributes to a greater bulk density and lower porosity and thereby to a lower WHC (So et al., 2009). Additionally, plowing can reduce the production of glomalin, and this reduction in turn decreases WSA (Borie et al., 
2006; Curaqueo et al., 2010; Curaqueo et al., 2011).

Positive correlations between organic C, glomalin fractions and physical soil properties were found, consistent with the results of other studies (Curaqueo et al., 2010; Curaqueo et al., 2011; Spohn and Giani, 2010). This consistency confirms the role played by glomalin as a soilaggregating agent. In general, it was found that the highest $\mathrm{OBC}$ dose positively influenced all the soil properties and, additionally, the grain yields, even under plowing management. This finding is in accordance with the results of previous reports (Alburquerque et al., 2013; Schulz et al., 2013).

\section{Conclusions}

The results of this study demonstrate a positive effect of oat hull biochar on $\mathrm{pH}$, electrical conductivity, total exchangeable bases, and barley yield in these volcanic soils. Glomalin fractions were strongly and positively correlated with soil physical properties such as water-stable aggregates, soil porosity and water-holding capacity. These properties were enhanced at the highest dose of oat hull biochar. This biochar amendment can be used as an alternative to organic wastes to improve the quality and fertility of volcanic soils. Additionally, it can be used as a complementary fertilizer in soils, exhibiting lower levels of fertility and degradation that limits the sustainability of the agroecosystem. The current investigation was a short-term study of the use of oat hull biochar in two volcanic soils of Chile. Long-term studies will be required to further corroborate the findings of this research.

\section{Acknowledgements}

We acknowledge the financial support provided by the National Commissions for Scientific and Technological Research (FONDECYT 3120213 Project). We also acknowledge the help and criticisms provided by Dr. Fernando Borie in reviewing this manuscript.

\section{References}

Alburquerque, J., Salazar, P., Barrón, V., Torrent, J., del Campillo, M.d., Gallardo, A., Villar, R. 2013. Enhanced wheat yield by biochar addition under different mineral fertilization levels. Agron Sustain Dev. 33,475-484.

Álvaro-Fuentes, J., Lopez, M.V., CanteroMartinez, C., Arrue, J.L. 2008. Tillage effects on soil organic carbon fractions in Mediterranean dryland agroecosystems. Soil Sci. Soc. Am. J. 72, 541-547.

Asai, H., Samson, B.K., Stephan, H.M., Songyikhangsuthor, K., Homma, K., Kiyono, Y., Inoue, Y., Shiraiwa, T., Horie, T. 2009. Biochar amendment techniques for upland rice production in Northern Laos: 1. Soil physical properties, leaf SPAD and grain yield. Field Crops Research. 111, 81-84.

Atkinson, C.J., Fitzgerald, J.D., Hipps, N.A. 2010. Potential mechanisms for achieving agricultural benefits from biochar application to temperate soils: a review. Plant and Soil. 337, 1-18.

Baronti, S., Alberti, G., Delle Vedove, G., Di Gennaro, F., Fellet, G., Genesio, L., Miglietta, F., Peressotti, A., Primo Vaccari, F. 2010. The biochar option to improve plant yields: First results from some field and pot experiments in Italy. Italian Journal of Agronomy. 5,3-11. 
Borie, F., Rubio, R., Rouanet, J.L., Morales, A., Borie, G., Rojas, C. 2006. Effects of tillage systems on soil characteristics, glomalin and mycorrhizal propagules in a Chilean Ultisol. Soil Till Res. 88, 253-261.

Curaqueo, G., Schoebitz, M., Borie, F., Caravaca, F., Roldán, A. 2014. Inoculation with arbuscular mycorrhizal fungi and addition of composted olive-mill waste enhance plant establishment and soil properties in the regeneration of a heavy metal-polluted environment. Environ Sci Pollut R. 21, 7403-7412.

Curaqueo, G., Acevedo, E., Cornejo, P., Seguel, A., Rubio, R., Borie, F. 2010. Tillage efffect on soil organic matter, mycorrhizal hyphae and aggregates in a mediterranean agroecosystem. Journal of Soil Science and Plant Nutrition. 10, 12-21.

Curaqueo, G., Barea, J.M., Acevedo, E., Rubio, R., Cornejo, P., Borie, F. 2011. Effects of different tillage system on arbuscular mycorrhizal fungal propagules and physical properties in a Mediterranean agroecosystem in central Chile. Soil and Tillage Research. 113,11-18.

Glaser, B., Lehmann, J., Zech, W. 2002. Ameliorating physical and chemical properties of highly weathered soils in the tropics with bio-char -: A review. Biol Fert Soils. 35, 219-230.

Gliessman, S. 2002. Agroecología: Procesos ecológicos en agricultura sostenible. CATIE, Turrialba, Costa Rica. 359 p.
Joseph, S.D., Camps-Arbestain, M., Lin, Y., Munroe, P., Chia, C.H., Hook, J., van Zwieten, L., Kimber, S., Cowie, A., Singh, B.P., Lehmann, J., Foidl, N., Smernik, R.J., Amonette, J.E. 2010. An investigation into the reactions of biochar in soil. Australian Journal of Soil Research. 48, 501-515.

Kemper, W.D., Rosenau, R.C. 1986. Aggregate stability and size distribution. Methods of soil analysis. Part I. Physical and mineralogical methods. American Society of Agronomy, Madison, Wisconsin. pp: 425-444.

Khan, N., Shea, S. 2013. Turf Root Enhancement by Amendment of Jandakot Sands of Western Australia with Different Rates of Biochar. J. Biobased Mater. Bio. 7, 715-723.

Kuzyakov, Y., Bogomolova, I., Glaser, B. 2014. Biochar stability in soil: Decomposition during eight years and transformation as assessed by compound-specific ${ }^{14} \mathrm{C}$ analysis. Soil Biology and Biochemistry. 70, 229-236.

Ladygina, N., Rineau, F. 2013. Biochar and Soil Biota CRC Press, Boca Raton, Fl. 270 p.

Laird, D.A., Fleming, P., Davis, D.D., Horton, R., Wang, B.Q., Karlen, D.L. 2010. Impact of biochar amendments on the quality of a typical Midwestern agricultural soil. Geoderma. 158, 443-449.

Lehmann, J., Joseph, S. (eds.) 2009. Biochar for Environmental Management: Science and Technology, pp. 1-416. Earthscan. 416 p., London, UK.

Liu, X.-H., Han, F.-P., Zhang, X.-C. 2012. Effect of Biochar on Soil Aggregates in the Loess Plateau: Results from Incubation Experiments. International Journal of Agriculture \& Biology. 14, 975-979. 
Major, J., Rondon, M., Molina, D., Riha, S., Lehmann, J. 2010. Maize yield and nutrition during 4 years after biochar application to a Colombian savanna oxisol. Plant and Soil. 333, 117-128.

Morales, A., Castillo, C., Rubio, R., Godoy, R., Rouanet, J.L., Borie, F. 2005. Niveles de glomalina en suelos de dos ecosistemas del sur de Chile. Revista de la Ciencia del suelo y Nutrición Vegetal. 5, 37-45.

Mukherjee, A., Lal, R. 2013. Biochar impacts on soil physical properties and Greenhouse gas emissions. Agronomy. 3, 313-339.

Mukherjee, A., Lal, R. 2014. The biochar dilemma. Soil Research. 52, 217-230.

Olsen, S., Sommers, L. 1982. Phosphorus. In: A. Page, et al., eds. Methods of Soil Analysis, Part 2. Chemical and microbiological properties. (Agronomy monograph $\mathrm{n}^{\circ}$. 9). Am. Soc. Agron. Soil Sci.Soc, Madison, Wisconsin. pp: 403-430.

Ouyang, L., Wang, F., Tang, J., Yu, L., Zhang, R. 2013. Effects of biochar amendment on soil aggregates and hydraulic properties. Journal of Soil Science and Plant Nutrition. 13, 9911002 .

Rillig, M.C., Mummey, D. 2006. Mycorrhizas and soil structure. New Phytol. 171,41-53.

Sadzawka, A., Carrasco, M., Grez, R., Mora, M. 2005. Métodos de análisis de compost. Centro Regional de Investigación La Platina. 142 p., Santiago de Chile, Chile.
Sadzawka, A., Carrasco, M.A., Grez, R., Mora, M., Flores, H., Neaman, A. 2006. Métodos de análisis recomendados para los suelos de Chile. Instituto de Investigaciones Agropecuarias. 164 p., Santiago de Chile, Chile.

Schulz, H., Dunst, G., Glaser, B. 2013. Positive effects of composted biochar on plant growth and soil fertility. Agron Sustain Dev. 33, 817-827.

So, H.B., Grabski, A., Desborough, P. 2009. The impact of 14 years of conventional and notill cultivation on the physical properties and crop yields of a loam soil at Grafton NSW, Australia. Soil Till Res. 104, 180-184.

Spohn, M., Giani, L. 2010. Water-stable aggregates, glomalin-related soil protein, and carbohydrates in a chronosequence of sandy hydromorphic soils. Soil Biology and Biochemistry. 42, 1505-1511.

Vaccari, F.P., Baronti, S., Lugato, E., Genesio, L., Castaldi, S., Fornasier, F., Miglietta, F. 2011. Biochar as a strategy to sequester carbon and increase yield in durum wheat. European Journal of Agronomy. 34, 231-238.

Valarini, P.J., Curaqueo, G., Seguel, A., Manzano, K., Rubio, R., Cornejo, P., Borie, F. 2009. Effect of compost application on some properties of a volcanic soil from central south Chile. Chil. J. Agr. Res. 69, 416-425. 
Varela Milla, O., Rivera, E., Huang, W.-J., Chien, C.-C., Wang, Y.-M. 2013. Agronomic properties and characterization of rice husk and wood biochars and their effect on the growth of water spinach in a field test. Journal of Soil Science and Plant Nutrition. 13,2 51-266.

Walkley, A., Black, A.L. 1934. An examination of the Degtjareff method for determining soil organic matter and a proposed modification of the chromic acid titration method. Soil Sci. 37,29-38.
Warnock, D.D., Mummey, D.L., McBride, B., Major, J., Lehmann, J., Rillig, M.C. 2010. Influences of non-herbaceous biochar on arbuscular mycorrhizal fungal abundances in roots and soils: Results from growthchamber and field experiments. Applied Soil Ecology. 46, 450-456.

Wright, S.F., Upadhyaya, A. 1996. Extraction of and abundant and unusual protein from soil and comparison with hyphal protein of arbuscular mycorrhizal fungi. Soil Sci. 161, 575-586. 